\title{
2
}

\section{PUBLICS AND AUDIENCES IN ANCIENT GREECE}

\author{
David Kawalko Roselli
}

Assessing audiences is a tricky business. Ancient critics crudely divided audiences into two opposed groups, while modern studies have tended to assimilate audiences with publics, or to eschew analysis given that audiences are comprised of individual spectators, each different in some respect. Whatever we say about audiences could (or will) be false in some sense, but the historical constitution of audiences should not be avoided (Kennedy 2009). Our knowledge of the theater, our interpretation of what theatrical signs could mean, is only possible "if it is based on the investigation of the meanings created by the respective cultural systems" (Fischer-Lichte 1982: 52). The crucial role of audiences was duly recognized in antiquity, and audience expectations were incorporated into dramatic production. The composition of plays, the selection of plays for performance by civic officials, and the physical performances by actors and musicians were all carried out with some idea of the desires, interests, and thoughts of the audience. Our understanding of the constitution of audiences not only shapes our sense of the possible reception of the plays themselves; it is also intimately connected with ancient and modern conceptions of the public (cf. Livingstone 2005); audiences and publics in antiquity have often been reconstituted to suit the demands of the modern state that emerged in the Enlightenment.

This chapter addresses the historical and ideological construction of theater audiences in ancient Greece, from the end of the Archaic age, through the Classical period, and down to the early Hellenistic world (ca. 500-300 BC). In a number of ancient philosophical and historical works, audiences are defined in terms of an educated and wealthy elite versus the "mob" or the "multitude." The audience as mob was part of a broader critique of the democratic regime associated with Athens: drama was assimilated to the city's democratic politics and critiqued on this basis. Indeed, there was some truth to the notion of the theater mob. Comedy in the fifth and early fourth centuries explicitly placed regular people of humble 
professions in the audience along with foreigners, women, and slaves; but there was also mention of "elite" individuals and citizens. More often the audience was hailed in general terms (e.g., "spectators") inclusive of the various social and political groups in the theater. Historical and archeological evidence, as I argue here, supports comedy's more nuanced picture of the audience.

Theater in ancient Athens and Greece in general was closely connected with ritual and the worship of the gods (typically, but not exclusively, Dionysus). In the sixth century BC tyrants took an active role in reconstituting and promoting large-scale festivals where drama was performed (Csapo and Miller 2007); with the concomitant rise of the city-state (polis [ $\pi$ ó $\lambda$ is]) institutional oversight passed to civic magistrates, and financial obligations were divided among public funds and private expenditure. Some scholars have connected closely the theater and democratic politics in Athens (Goldhill 1990; Vernant 1988 [1972]; Wilson 2009); others have shifted attention to a consideration of the polis rather than Athenian democracy as the frame of drama (Carter 2011a; Rhodes 2003). Politics was an important part of the theater (Carter 2011a), and theater was readily politicized. Yet, as I discuss further later, the political was only one constitutive element of the theater and its audiences. The shift of focus from democratic politics and thus citizens to the polis community is helpful in terms of its broader scope, but it too can obscure non-Greeks (and non-citizens) within the polis.

The spread of drama throughout Attica and the Greek-speaking world occurred in tandem with the birth of a theater industry playing to increasingly larger audiences and employing increasingly professionalized performers (Csapo 2010). Three dramatic genres - tragedy, satyr drama, and comedy - were represented at most festivals, both in Athens (City Dionysia, Lenaia) and in the more numerous festivals in the Attic villages or demes (Rural Dionysia); dramatic festivals in Macedon, in the northern and eastern Aegean Sea (Lemnos, Rhodes, Samos), and in other parts of Greece contributed to the spread of drama. There was a vibrant theater culture in Sicily and South Italy, where Attic plays were also performed (Bosher 2012). In all of these cities, but especially in Athens, which was closely associated with drama throughout the Greek world, theater was politicized particularly with respect to the act of adjudication among audiences. Ancient critics hostile to an undisciplined democratic culture railed against the authority of this "public," while comic poets actively solicited favorable responses from various members of its audience.

In this chapter, I first sketch out the dominant ways in which modern scholars have defined ancient audiences. I argue that attention to (male) citizenship or Greek identity has effaced the presence and role of other groups in the audience. In the second section I discuss the evidence for audiences in ancient Athens. Available space for spectators and the various barriers to these spaces shaped the diverse constitution of audiences; from the Classical to early Hellenistic period (ca. 480-300 BC), theaters did not merely expand and proliferate but redefined the make-up of audiences. The third section explores the discourse of the audience in ancient sources. As I briefly discuss in the conclusion, this chapter aims to unsettle and provincialize the idea of ancient audiences as publics in ancient Greece. 


\section{Modern views of ancient audiences}

Despite the influential emphasis in Aristotle's Poetics on the individual's emotional

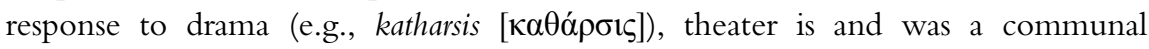
and social event. The response of the individual in the audience is influenced and shaped by broader social forces (Ubersfeld 1981: 306). Thinking about audiences in terms of broadly defined groups, made up of people with various sorts of shared social values, avoids the pitfalls of assuming a monolithic mass audience or disavowing an analysis of social relations. A limited number of passing references to specific individuals in ancient audiences are extant, but it is arguably more important to approach the study of drama in terms of spectators' "culturally constituted horizon of expectations" (Bennett 1997: 211) and the categories (e.g., social, political, ethnic) that shape individuals' consciousness.

Life in ancient Athens was defined and experienced through a number of categories and concepts. Ethnicity (Greek/non-Greek), civic status (free/slave), citizenship, class (destitute/poor/"middle"/rich), and gender were constitutive of spectators' horizons of expectations. Age groups were also significant, and it is clear that minors did attend the theater (e.g., Aristophanes Peace 50-53; Menander Dyscolus 965-967). But age was more readily assimilated to broader categories: the older generation in comedy often symbolizes more traditional (i.e., conservative) social values (Csapo 2002: 127-135). Plato can thus refer to minors in the audience to critique the theater of the "radical" democracy and its citizen spectators (Laws $658 \mathrm{a}-\mathrm{e})$; a similar strategy is at work with Plato's description of tragedy's audience as a demos $(\delta \tilde{\eta} \mu \mathrm{os})$ consisting of women, slaves, and minors (Gorgias $502 \mathrm{~b}-\mathrm{d}$; cf. Aristophanes Frogs 949-951). Demos can refer to the inhabitants of an area, the common people, or more commonly, the citizen body; Plato thus ironically categorizes the audience, conflating citizens with non-citizens. Citizen spectators under the radical democracy are here scrutinized in terms of their suitability to adjudicate at such public gatherings. It is worth noting that citizenship in Athens (after Pericles' citizenship law of $451 \mathrm{BC}$ ) was based on Athenian parentage but not class or profession (as in many Greek cities); this relatively "democratic" stance regarding citizenship nonetheless omitted the bulk of the population from the privileges and protections afforded by citizenship.

By ignoring or failing to recognize the large number of women, foreigners, and slaves - along with due consideration of class differentiation - among the audience, many modern studies reproduce the systemic inequalities in ancient Greece by applying to the theater the importance that citizenship had for political institutions (e.g., Goldhill 1994, 1997). Approaching ancient Greek theater in terms of citizen audiences is part of a modern trend in thinking about crowds, audiences, and the nation-state (Butsch 2008). In a move similar to Jürgen Habermas' analysis of the concept of the "public sphere," modern studies of audiences suppress variant "spheres" in the theater and exclude them from the historical process (Habermas 1989; cf. Calhoun 1992). Such studies recapitulate the discourse of audiences emerging from the Enlightenment that placed a premium on "worthiness" for 
citizenship; culture emerged as a discrete sphere in which to form certain kinds of subjects and a certain kind of subjectivity requisite for identifying with the state (Lloyd and Thomas 1998). The theater as a means to benefit civil society became a dominant preoccupation in eighteenth-century France (Ravel 1999); theater thus appears as a testing ground for citizenship or a type of political pedagogy. Similarly in Friedrich Schiller's essay from 1784, "On the Stage as a Moral Institution," the ancient theater offers a model for the formation of subjects as citizens in the service of the state: "Where the influence of civil law ends, that of the stage begins" (Schiller 1895 [1794]: 340).

Earlier studies conducted by historians of the ancient theater reflected their antiquarian interests. Extensive lists of references were compiled and most often interpreted without much concern for anachronism; thus in Arthur Pickard-Cambridge's magisterial study, The Dramatic Festivals of Athens, theater "tickets" are too comfortably attributed to ancient Greece (Pickard-Cambridge 1988: 270-272). Pickard-Cambridge did leave open the possibility of a limited presence of non-citizen spectators without considering its implications, but subsequent studies have gradually come to focus on audiences in terms of publics. For example, in the 1970s a number of Italian Marxists explored drama (especially tragedy) as an "ideological state apparatus" with audiences closely connected with the state and its citizens (e.g., Citti 1979; di Benedetto 1971). The rising importance of performance studies (see more later) led classical scholars to recognize that much was at stake with the constitution of ancient audiences for their analyses of the "function (s)" of drama, but little work was done to assess these audiences.

Beginning in the 1980 s, approaching ancient drama in terms of citizen males became the dominant mode of interpretation. According to such "Athenocentric" models, which came of age near the end of the Cold War, the audience is a "homogeneous citizen body," and "Athenian drama was preoccupied.with constructing the Athenian citizen (polites) as a subject" (Wiles 1997: 212). Harkening back to its Enlightenment roots, the idea of ancient theater as a laboratory for inculcating civic or democratic ideology (e.g., Goldhill 2000) blurs the crucial distinction between theater audiences and the citizen body (demos); the emphasis in such studies on political deliberation as a way to foster active citizenship in the theater occludes other representative ways of thinking and registering experience in drama (e.g., emotions, intimacy). This model further reflects the ideologically freighted structuralist binary of self and other, thus downplaying historical and material conditions; with its focus on the Athenian "democratic" context, consideration of the role of non-citizen spectators in producing theater is left out of the equation. If tragedy builds community through performance (Wiles 2011), the contribution of non-citizens to theater - particularly in Athens with its large population of metics, slaves, and women participating at dramatic festivals - opens up a space for constituting publics formed alongside or outside of the realm of citizenship (e.g., in terms of professions, neighborhoods, ethnicity).

With women excluded from audiences or their presence downplayed, female characters were influentially viewed as a means to provide a "fuller model for the 
masculine self' indistinguishable from that of citizens (Zeitlin 1996: 363). Since other sorts of non-citizen spectators - slaves, metics (i.e., foreigners and/or freed slaves officially residing in Athens), foreign visitors or dignitaries - have been relatively ignored, non-citizen dramatic characters are viewed in terms of their significance for Athenians (Hall 1989; Tzanetou 2012). Although some studies have moved away from narrowly Athenocentric models, the specter of citizen male audiences still haunts them (e.g., Burian 2011; Rehm 2007). One may wonder whether a particular model of the audience has been successfully adopted for the purpose of approaching ancient drama in terms of citizenship and the state.

Additional models of the ancient audience are informed by the study of drama in terms of performance. Attention to performance studies in the 1970s ushered in a shift away from the traditional focus on texts and authors. Some scholars began to study drama in terms of performers (e.g., actors, musicians, choral trainers), social institutions (e.g., festivals), economic organization, and audiences. Theater history competed with the dominant literary and philological analyses of specific plays carried out in Classics Departments (Csapo 1999-2000). Yet even with its attention to audiences, theater history in the US tended to downplay sociological, especially Marxist, aspects of theater production (Shepherd and Wallis 2004: 52-53).

Scholars working in performance studies have viewed ancient audiences as "mixed" and "included anyone who could afford a ticket" (Rehm 2002: 50). The absence (or refusal) of a clearer picture of audience constitution has led to the uncritical assessment of Greek drama in terms often more relevant and meaningful to our own modern experiences. Much like Pickard-Cambridge's anachronistic reference to tickets, a generically mixed audience -nonetheless defined in terms of expenditure - overlooks other kinds of non-paying spectators (as I discuss later). "Mixed" is an alibi for the universal spectator: the contingencies of regionalism, class, and gender among audiences are suppressed in a tactic familiar from the Enlightenment discourse of spectatorship anchored as it was to particular ideas about representation and the state. Another offshoot of performance studies has helpfully studied the production of Athenian plays in Greek Sicily and South Italy. The exportation of "Athenian" drama to these populations has prompted questioning of the scholarly emphasis on "Athenian" citizenship. But in place of the Athenocentric model we find a "Hellenocentric" focus that excludes nonGreeks (Easterling 1994; Taplin 1999). Much like the view of the audience as "mixed," the Hellenocentric model incorporates a universalizing approach to audiences. The discursive framework of these studies threatens to silence the more numerous non-citizen "minorities" and to obscure class difference.

To be sure, there have been a limited number of studies addressing the presence of non-citizens in ancient audiences (e.g., Carter 2011b; Spineto 2005: 277-292). It is worth stressing, however, that much debate has centered on women's attendance (Roselli 2011: 158-194). Gender has been a more congenial scholarly focus than class or ethnicity. Scholars have argued about the presence of female spectators in terms of drama's political context (excluding women) or ritual context (including women), but even those scholars accepting female spectators tend to cast them as 
subject to the normative (male) values and inscribed within masculine (citizen) ideology. The influential idea of a "notional" male audience (Henderson 1991: 146) has contributed to these tendencies. Whereas audiences are rarely (if at all) officially addressed in tragedy and the meager remains of satyr drama, comedy did refer explicitly to males, even citizens, in the audience (e.g., Aristophanes Birds 30; Lysistrata 638). But even when comedy traditionally refers to "males," there is some indication that female spectators are subsumed into this category (Henderson 1991: 140). Additionally, given the grammatical tendency in the ancient Greek language to refer to a group of males and females with an adjective or participle in the masculine form, the gender of $\theta \varepsilon \omega \mu \varepsilon v o r$ or "spectators" (e.g., Aristophanes Assembly Women 888, cf. 582-583) is indeed masculine but does not necessarily exclude non-male spectators. Menander completes an address to spectators by referring simply to "everyone" (Women from Samos 734).

Comedy addresses its audiences indiscriminately as citizens and non-citizens. Yet it is notable that even citizens could be made from elsewhere: naturalization was not common but nonetheless enabled non-Athenians to become citizens (Cohen 2000; Osborne 1981-1983). The model of audiences as publics has skewed our understanding of drama in terms of male citizen interests, thus suppressing non-hegemonic groups or variant "public spheres." It also fails to take account of the evidence for actual audiences.

\section{Ancient theaters and audiences}

Attending the theater was restricted by a number of barriers that were in part addressed by the polis or readily circumvented by the population of Athens. Given the limited evidence, the historical demography is much debated, but the broad outlines are clear (Akrigg 2007). Citizens were a vastly outnumbered minority, as were wealthy families. Xenophon's critique of the late fifth-century composition of the Assembly in terms of the large number of craftsmen, tradesmen, and anyone who "buys cheap and sells dear" (Memorabilia 3.7.6) attests a demographic shift among the citizenry and registers elite resentment against urban workers. Agriculture was the dominant industry, but commercial labor played a more significant role in the economy than has been thought (Harris 2002). Since metics could not own land, most of them were engaged in commercial business; they were not viewed as full members of the community in elite political texts (Aristotle Politics 1278a38). Elite sources critiqued urban citizen laborers in terms of their questionable worthiness of citizenship and their support for radical democracy. In contrast, Aristophanes appeals to craftsmen (citizens and non-citizens alike) in the audience (e.g., Peace 543-545) for their support.

Theater was wildly popular among these people. The little evidence we do have for spectators' experiences suggest revelry (e.g., Aristotle Nicomachean Ethics 1175b12; Philochorus Atthis, FrGHist 328 F 171); Horace could later remark that these audiences were drunk (Ars poetica 224). Given the numerous stories of theater audiences acting boisterously and shouting loudly while critiquing performances 
(Roselli 2011: 44-51), it is not surprising that we hear of some kind of "theater police" - perhaps connected with the Archon's attendants (cf. Demosthenes 21.60) - maintaining order in the theater (Plato Laws 700c; cf. Aristoxenus fr. 29 da Rios). Dramatic festivals were also a moment for romantic encounters imagined or real (cf. Aristophanes Birds 794-796; Menander fr. 337 K-A) - and for common interaction and exchanges among various social groups that promoted (or potentially shaped) forms of social identity transcending citizenship in the space of the theater (cf. Vlassopoulos 2007). Finally, there are numerous stories about people travelling long distances to watch a performance (e.g., Xenophon Oeconomicus 3.8; Plato Republic 475d) and numerous artifacts (vase paintings, figurines) attesting the widespread interest in drama (Csapo 2010; Green 1994).

The best evidence, however, for the spread of the theater and the rising interest in drama among eager theatergoers is the building explosion with respect to theaters and dramatic festivals (Csapo 2010: 89-103). Athenians invested vast sums in drama; poets officially elected by the state were paid handsomely. Plutarch could thus quip that they spent more on productions of Bacchae and Oedipus than on protecting their empire (Moralia 349b). Plutarch (or his source) exaggerates, but the perception was real (Wilson 2008). Yet it is crucial to note that Athens was not the only city subject to theater-mania. Cities in South Italy and Syracuse were very receptive to Attic drama. Stories about Athenians captured in 413 BC in Syracuse and "saved by Euripides" (e.g., Plutarch Nicias 29.1) - they gained their freedom by singing tragic songs to eager Syracusans - point to an avid audience in Athens and in Sicily. Since metics also served in the Athenian military and the Sicilians sold the captured slaves (Plutarch Nicias 28.3), metics are to be included among the singers of Euripidean songs to their Sicilian captors.

Large numbers of non-citizens took part in the theater. Foreigners and metics were present as spectators, performers, and financiers at dramatic festivals (e.g., Aristophanes Acharnians 507-508; $\Sigma$ Aristophanes Wealth 953; Kaimio 1999). Numerous stories describe fights over limited seating among citizens and non-citizens, rich and poor (Roselli 2011: 96-97). Slaves reportedly went to the various deme festivals "making much uproar" (Plutarch Moralia 1098b; cf. Aristophanes Acharnians 249-260) or to accompany their master (Theophrastus Characters 9.5). As noted earlier, the issue of women's attendance has been contentious in modern times. This debate emerged in the eighteenth century with Karl Böttiger's arguments against their presence (1837 [1796]); much of the discussion was unduly shaped by the discourse of citizenship and the nation-state emerging in the Enlightenment (Katz 1998), but there is solid evidence for female spectators (Roselli 2011: 158-194): ancient sources reflect critical discussion of women's attendance but did not question it. Whereas women were excluded from performing but not from audiences, non-citizens were involved in nearly all aspects of the theater, from performing on stage to financing productions.

Audience space and thus constitution changed in significant ways from the early Classical to the Hellenistic period (Roselli 2011: 63-117). Fifth-century Attic theaters for the most part had wooden seating constructed by entrepreneurs who leased the 
space from the city and stood to profit handsomely from entrance fees (Csapo 2007); the seating area in the Theater of Dionysus in Athens held 3,700 to 7,000, and extant deme theaters held 2,000-3,000 spectators. Seating down front (prohedria $[\pi \rho 0 \varepsilon \delta \rho i ́ \alpha])$ was reserved for civic officials and employees (including public slaves), as well as foreign dignitaries honored by the state. Whereas these people watched for free, the rest of the audience on the wooden benches had to pay cash for their seats. The effects of limited space and financial barriers were mitigated by two factors. First, distributions of state funds (theorika [ $\theta \varepsilon \omega \rho \iota \kappa \alpha ́])$ to Athenian citizens for festival attendance were introduced around 450 BC (Roselli 2011: 87-117). Second, the availability of unofficial viewing spaces on the theater's hillside enabled thousands of non-citizens to watch the performances. The fifth-century comic poet Cratinus referred to one such unofficial space in Athens as the "view from the poplar tree" (fr. $372 \mathrm{~K}-\mathrm{A}$ ). The proverbial status of this space in ancient sources (Scullion 1994: 55-57), describing it as full of those unable to find or afford a seat, gives some sense of its popularity.

Ten judges were officially selected by the state to oversee dramatic competitions (Marshall and van Willigenburg 2004). But Old Comedy typically attempted to harness the energies and capture the attention of its audiences qua judges, most often in a bid to encourage spectators to shout in support of the performance (e.g., Aristophanes Clouds 518-522, Birds 445-446; cf. Assembly Women 1160). Given comedy's open remarks about winning over its fickle audiences (e.g., Aristophanes Knights 516-518; cf. Peace 43-45), direct appeals to spectators are not surprising. The ten official judges, those honored by the state, and the paying spectators were not the sole adjudicators; the "unofficial audience" (e.g., from the poplar) was also deemed worthy of public recognition and, most likely, solicitation. Failure to manage audiences could prove disastrous. One tragic production was forced to end the show given the angry response from the audience over an actor's mistake (Aristotle Poetics 1455a21-29). When one comic poet, Platon, faired poorly at the premier festival, the City Dionysia, he was allegedly "pushed back" to another festival for his next production (cf. Aristophanes fr. 590 K-A; Csapo and Slater 1995: 135).

Fourth-century theaters were both more numerous and much larger. The Theater of Dionysus in Athens was rebuilt in stone and enlarged to accommodate around 16,000 spectators (the footprint of this theater is what we now see in Athens); deme theaters also expanded to hold audiences of up to 5,000. Theorika continued to be distributed to citizens (at least down to ca. $317 \mathrm{BC}$ ), but unofficial spaces were mostly occupied by stone seating that now required payment to the state: entrance fees were thus "democratically" extended to all spectators. Reserved honorary seating down front was vastly expanded with additional ranks of civic officials and employees, as well as those officially honored by the state. With the possible exception of honorary seats for priestesses (Connelly 2007: 205-214; Schnurr-Redford 1995: 210-222), these spectators who benefited the state were almost entirely male. The creation of this more prominent "men only" area in the audience down front may have given the impression of an "official" male 
audience with women relegated to the back of the auditorium. References to separate seating areas for women (e.g., Alexis Gynecocracy fr. 42 K-A; $\Sigma$ Aristophanes Assembly Women 22), I suggest, reflect the perception produced by such seating arrangements rather than the reality of seating arrangements in the auditorium.

The theater now presented a more clearly defined picture of the city's social and political hierarchy down front, with its expanded space and more elaborate segmentation. But the new theater also effaced the legible presence of unofficial (i.e., poor and subaltern) spectators. Two sections were thus created: those officially recognized and honored by the state and the monetized audience united through its financial relationship with dramatic festivals. As a result, the competing interests of society requiring negotiation became less visible. The expansion of theaters was connected with the city officials' broader economic interests (i.e., the state now profited directly from entrance fees), but a key consequence (if not a goal) was the elimination of unregulated and unofficial seating areas freely available to everyone. By the end of the fourth century the state oversaw the entire audience and profited from most of it.

\section{Categorizing audiences in ancient Greece}

The Aristotelian audience was infamously described by Bertolt Brecht as a "shapeless dumpling in the stockpot of emotions" (1964: 143). This view of the audience as an undifferentiated mass is partially represented in elite texts critical of the role of spectators qua mob in dramatic production, but even these texts represented the audience as more complex. Instead of Brecht's "shapeless dumpling," elite sources such as Aristotle proposed a crude division in the audience between the elite and everyone else. However, plays (comedy explicitly) often engaged the audience as a collective in the theater, and this aspect is particularly important for understanding the spectators' authoritative role and competence in adjudicating musical and poetic competitions (Roselli 2011: 36-41). The notion of spectators' "theatrical competence" further complicates the notion of an undifferentiated mass by positing the variable skills possessed by different members of the audience: while some spectators may possess more education and/or experience with performance for decoding drama, audience members need only possess a bare minimum of skills (e.g., linguistic, visual, cultural) to make sense of and enjoy a performance (Revermann 2006: 105-115). Despite the at times misleading view of audiences presented in elite sources, they provide a window into the ways ancient Greeks conceptualized audiences.

The specter of a divided audience (elite individuals versus the masses) is elaborated in Aristotle's discussion of the psychological effects of music (cf. Plato Laws 659b1-5). There are two kinds of spectators (Politics 1342a18-21): one is "leisure class" and

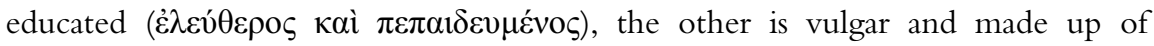
craftsmen, wage-laborers, and other kinds of workers (

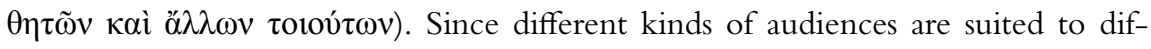
ferent kinds of music, performers of "theatrical music" are expected to perform as 
representatives of the vulgar and base to appeal to the predominantly vulgar audiences of festival competitions (Politics 1341b11-14; Rhetoric 1403b31-35). The influence of the audience on poets is also what led to the popularization of inferior plot structures (Poetics 1452a7-12; cf. Plato Gorgias 501e-502c). For Plato, mimetic poets were popular with mass audiences, because they were attuned to people's peevish and variegated (poikilos [ $\pi$ oikílos]) character (Republic 604e). Changes to music and performance associated with the highly mimetic "New Music" were politicized as appealing to women, foreigners, and radical democratic citizens (Csapo 2004). Aristotle contentiously claimed that the "well-known" or traditional stories of tragedy were well known only to a few but nonetheless pleased all (Poetics 1451b24-26; cf. Antiphanes Poetry fr. 189 K-A), but the vast number of artifacts connected with tragedy suggests rather a broad familiarity with the tragic theater (Csapo 2010; Taplin 2007). The idea of the divided audience was a way for ancient critics (and modern scholars) to ascribe the degeneration and corruption of the theater to the "base" majority (Walcot 1971: 46-48).

Differences between reading and watching a tragedy are also framed in terms of the divided audience. While Aristotle grants that seeing likenesses is a part of mimesis that gives pleasure by enabling the viewer to learn or infer meaning (Poetics 1448b4-19), he nonetheless separates out from tragedy the element of spectacle along with the dramatic competition and the actors - as the least artistic part of poetry $(1450 \mathrm{~b} 16-20)$. Aristotle claims that the production of spectacle is more dependent on the skill of the stage-property maker, a working-class professional (cf. Aristophanes Knights 232), than the skill of elite poets. It is through reading that one recognizes the genre of tragedy, not through the element of spectacle tainted by its association with theater workers and vulgar spectators (Poetics 1462a3-13). Displacing spectacle with reading, Aristotle redefines drama as an elite and relatively private cultural product far from the assembled multitude and professional performers in the theater.

Dividing the audience ideologically into these two groups was a useful way of explaining away the "debased" form of contemporaneous drama. It also acknowledged the reality of the collective audience's adjudicatory role at dramatic competitions. The so-called Old Oligarch predictably had little sympathy with the audience's pleasure in watching the rich, noble, and powerful ridiculed in Old Comedy (Xenophon Athenaion Politeia 2.18); he refers to the theater audience as demos and "mob" ( $(\grave{\text { ò }} \pi \lambda \tilde{\eta} \theta 0 \varsigma)$. The anxiety felt by conservative critics was not unjustified (Csapo 2000: 132): although some elite spectators enjoyed Old Comedy (Xenophon Oeconomicus 3.7), it typically embodied the values and interests of the poor (e.g., Aristophanes Peace 562-3), and more generally those of the "underdog" (Henderson 1993; Roselli forthcoming). The dominant view of the world in Old Comedy was conditioned by political and social conditions at the height of the "radical" democracy in Athens, when wealth was nonetheless connected with political influence and prestige. While recognizing the powerful role of cultural production in shaping politics, these critical sources direct their hostility to the adjudicative authority assumed by theater audiences and to the political uses of popular drama. 
Somewhat surprisingly there is a passage in Aristophanes's Clouds (527) that, much like the elite critics, appears to divide the audience into two groups: the intelligent few and all the rest. The audience was usually invoked in comedy as a collective encouraged to voice approval for the production (as noted earlier); alternatively, comic poets could openly (and strategically) vilify the audience for amusement (Revermann 2006). The passage in Clouds subtly differs from these trends, but there is a textual variant in the manuscripts that has the chorus refer to a collective (i.e., all "you clever people") rather than a divided group (Csapo 2000: 131). Clouds faired poorly at its premier and was subsequently revised but not produced. The revised play (i.e., the text we now possess) does refer to the poet's unhappiness with the audience's apparent lack of appreciation (518-62) - thus eliding the difference between the official ten judges and the audience as arbiter. But Clouds was revised for readers: the anomalous variant of a clever subgroup can be explained by the smaller number of readers of the revised script versus the many who did not "enjoy" its premier and made their views known publicly (cf. Aristotle Poetics 1455a21-29). Readership was further distinguished from participation by its separation from performers (e.g., the influence of performers, stage-hands, and trainers) and from the dramatic competition (e.g., the need to manage large groups of spectators).

From these critical views of audiences, relations between spectators and performance were contentious. In particular, the role of audiences as unofficial judges influencing dramatic production was a flashpoint of ideological struggle. A popular politician in Thucydides' History (3.37-3.38) defines theater audiences as comprised of passive and non-political subjects; political deliberation in the Assembly is represented as having degenerated into the adjudication of such audiences. The point of the comparison is to remodel the citizens in the Assembly as a more critical audience (Wohl 2002: 96). In Aristotle's discussion of democracy in Politics (1281b), the multitude or "mob" ( $\tau$ ò $\pi \lambda \tilde{\eta} \theta 0 \varsigma$ ) is an efficient judge of musical and poetic competitions. Whereas a single individual among the masses may not be worth much consideration, when people come together collectively and pool their moral and intellectual facilities, they are better than even the elite individual. Aristotle is, however, notably skeptical that the collective is always superior to an elite few. His theoretical remarks on the wisdom of the multitude reveal the potential value of the collective audience while highlighting the perceived unevenness of theatrical or political competency among individuals. Audiences in Athens, however, were not merely theoretical. As notedearlier, Aristotle took issue with its actual audiences of craftsmen, foreigners, and slaves. These critical views were sufficiently popular to surface in a fourth-century comedy: a character claims that it is shameful to judge noble and beautiful things by the vote of the many (Adespota fr. $139 \mathrm{~K}-\mathrm{A}$; cf. Menander fr. $743 \mathrm{~K}-\mathrm{A}$ ). Although there is no indication of the reception of this view in the play, such sentiments became topical.

According to Plato, the "true judge" should ignore instruction from those in the audience ( $\pi \alpha \rho \grave{\alpha} \theta \varepsilon \alpha \dot{\tau} \tau \rho)$ ) and not be distracted by the noise of the many ( $\theta$ opúßov $\tau \tilde{\omega} \nu \pi \mathrm{o} \lambda \lambda \tilde{\omega} v)$. Judges should be the teachers of the audience and not vice versa, as 
is currently practiced (Laws 659a-c). The problem is that the "true" or best judges are not heeded, and audiences unduly influence weak or cowardly judges; in Plato's Symposium theater audiences are associated with "intellectual weakness" (Emlyn-Jones 2004). In the "good old days" public authorities understood the differences between musical forms and genres (Laws 700c-701b); knowledge and discipline were not within the purview of popular musicians, the mob's unmusical shouting, or the clapping of applause - as happens nowadays. Back then the "disciplining rod" was used on children, their tutors (i.e., slaves), and the rest of the crowd to maintain order. But subsequently it became common to claim that music had no correct standards except for the pleasure it provided to audiences. The "mob" (Laws 700d: $\tau$ ò $\pi \lambda \tilde{\eta} \theta 0 \varsigma$ ) was encouraged to think that it was capable of passing judgment on theatrical performances, and as a result a "degenerate

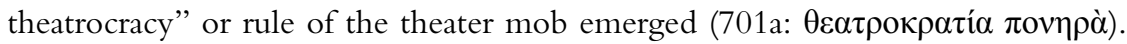

In Plato's tendentious historical construction, the majority of the crowd usurped the proper role of elite men, who controlled the state and were the judges of cultural production. The mass audience is a potent symbol not only for the alleged ills of democracy but also for the threat of disruption to Plato's ideal organization of society. Elite youth could be easily caught up with such a crowd, and their education corrupted by the audiences' indiscriminate judgments: the elite youth would end up mimicking the multitude (Republic 492b-c). Theater and politics are intimately connected. Since Plato argues that the rise of democracy coincides with the poor recognizing that they are superior in force to the wealthy oligarchs (557a), similar sentiments shared by theater audiences could transform the theater into a site that empowers spectators and threatens traditional civic order. Given that theater audiences for Plato include men and women, slave and free, Athenians and Greeks (e.g., Gorgias 502b-d; Symposium 175e), Plato's "theatrocracy" describes a bloc that cuts across the boundaries of male/female, citizen/non-citizen, slave/free. Adjudication in the theater by these audiences was a subversive practice that could spill over into the realm of politics, where the subaltern had no (or only very little) influence. With Jacques Rancière we might categorize this potential disruption as true politics - the claim for a part in society by those who otherwise had no part (Rancière 2004).

\section{Conclusion: audiences and publics}

Modern scholars have tended to assimilate ancient Greek audiences to citizen spectators with dramatic performance understood in terms of an ethical pedagogy for the state. Such models replay aspects of ancient criticism on audiences that were subsequently anchored in post-Enlightenment thinking about the connections between drama and politics, theater and state. Although there is evidence for significant changes in the make-up of ancient audiences in Athens from the Classical to Hellenistic periods, audiences were nonetheless legibly diverse and represented the citizen body only in limited ways. It was precisely the presence of non-citizens and the large numbers of the poor - both citizen and non-citizen - voicing 
collective judgment that elicited the anxiety and criticism of ancient critics: audiences of free male citizens were recognized as a fantasy (cf. Plato Laws 701a). The prevalent idea of ancient audiences as publics has less to do with their historical constitution than with the ideological foundations of the modern state.

Modern political philosophers (e.g., Arendt 1958; Habermas 1989) have treated Plato and Aristotle's normative prescriptions of Athenian democracy as descriptive of the polis. As a result, the realm of the polis and male citizens has often been viewed as separate from the realm of the oikos (household) and thus separate from making a living or physical survival. This tendency in modern studies to idealize separate private and public realms has been aided by misconceptions about the ancient economy and politics with trade and manufacture seen as the purview of slaves and metics. However, the evidence is clear: citizens (alongside slave and metics) were extensively involved both in trade and manufacture despite the denigration of manual labor(ers) articulated by Aristotle and Plato as a way to resolve the perceived problems of radical democracy by disenfranchising lower-class craftsmen. Study of the ancient theater and its audiences suggests that the separation of public and private that pervades modern studies was only partial. The institution of theorika primarily benefiting poor citizens during the dramatic festivals - attests the rise of the social to the extent that economic conditions of private families became publicly significant. As Marx noted, "the separation of civil society and political state as two different spheres" arises with the modern bourgeoisie (Marx 1975 [1843]: 32); the resultant emphasis on the individual as representative of the state and abstracted from contingencies of gender, class, or civic status has had a profound effect on our understanding of audiences and publics.

Theater in ancient Athens was part of a festival in honor of Dionysus (a god notoriously accessible to all) that was nonetheless officially aligned with the polis. It was a public sphere to the extent that it was an institution engaging critical debate about the community; it contributed to the organization of social life beyond the boundaries of family and state. Habermas notes that the "public sphere was constituted through discussion" and thus extended to the agora, courts, or the "common action" of warfare or athletic competitions (Habermas 1989: 3). Although the bourgeois theater plays an important role in Habermas' study of the public sphere (Habermas 1989: 38-43), the theater is notably omitted from his brief analysis of ancient examples. Ancient theater audiences were inclusive in ways that Habermas' public sphere is not: they constituted rather a particular kind of public including but not comprised solely of citizens (as with courts), involved with but not determined by the market (as in the agora).

Audiences comprised of these "other," mostly subaltern, publics - non-citizens, the poor, women, slaves, and metics - engaged in public acts of adjudication (typically understood as political) in a space constituted by the interrelated practices of the economic, political, cultural, and educational. Critiques of the theater in democratic Athens from the fifth to early fourth centuries attest the potential and real effects of these audiences on the style, content, and reception of drama. At the same time, Greek drama has rightly been viewed as contributing to the discourse of 
the state and the formation of civic ideology (e.g., concerning such issues as politics, empire, war). Given that audiences at dramatic festivals could determine the success of a production and influence the selection of plays to be performed, this "civic discourse" was thus to a certain extent underwritten by the subaltern community. It is important to note that there were important structural and ideological transformations of audiences and theaters from the Classical to the Hellenistic period; the later fourth-century theater was constituted and defined more rigorously by the dominant class - a wealthy elite from and/or sponsored by Macedon with no interest in radical democracy. Nonetheless, the theater served as a sphere in which non-citizen subalterns (and poor citizens) could shape the construction of civic ideology and simultaneously extend the purview of drama beyond the political world of citizens and citizenship.

\section{Abbreviations}

K-A = Kassel, R. and Austin, C. (1983-) Poetae Comici Graeci, Berlin: de Gruyter.

\section{References}

Akrigg, B. (2007) 'The nature and implications of Athens' changed social structure and economy', in R. Osborne (ed.), Debating the Athenian Cultural Revolution, Cambridge: Cambridge University Press, pp. 27-43.

Arendt, H. (1958) The Human Condition, Chicago, IL: University of Chicago Press.

Bennett, S. (1997) Theatre Audiences: A Theory of Production and Reception, 2nd edn, New York: Routledge.

Bosher, K. (ed.) (2012) Theater Outside Athens: Drama in Greek Sicily and South Italy, Cambridge: Cambridge University Press.

Böttiger, K. A. (1837 [1796]) 'Waren die Frauen in Athen Zuschauerinnen bei den dramatischen Vorstellungen?', in J. Sillig (ed.), Kleine Schriften, vol. 1, Dresden: Arnold, pp. 295-307.

Brecht, B. (1964) Brecht on Theater, trans. J. Willett, London: Hill and Wang.

Burian, P. (2011) 'Athenian tragedy as democratic discourse', in D. Carter (ed.), Why Athens? A Reappraisal of Tragic Politics, Oxford: Oxford University Press, pp. 95-118.

Butsch, R. (2008) The Citizen Audience: Crowds, Publics, and Individuals, New York: Routledge.

Calhoun, C. (ed.) (1992) Habermas and the Public Sphere, Cambridge, MA: MIT Press.

Carter, D. (ed.) (2011a) Why Athens? A Reappraisal of Tragic Politics, Oxford: Oxford University Press.

- (2011b) 'Plato, drama, and rhetoric', in D. Carter (ed.), Why Athens? A Reappraisal of Tragic Politics, Oxford: Oxford University Press, pp. 45-68.

Citti, V. (1979) Tragedia e lotta di classe in Grecia, Naples: Liguori.

Cohen, D. (2000) The Athenian Nation, Princeton, NJ: Princeton University Press.

Connelly, J. B. (2007) Portrait of a Priestess: Women and Ritual in Ancient Greece, Princeton, NJ: Princeton University Press.

Csapo, E. (1999-2000) 'Performance and reception: Introduction', Illinois Classical Studies, 24-25: 295-302.

(2000) 'From Aristophanes to Menander? Genre transformation in Greek comedy', in M. Depew and D. Obbink (eds.), Matrices of Genre, Cambridge, MA: Harvard University Press, pp. 115-134.

(2002) 'Kallippides on the floor-sweepings: The limits of realism in classical acting and performance styles', in P. Easterling and E. Hall (eds.), Greek and Roman Actors: Aspects of an Ancient Profession, Cambridge: Cambridge University Press, pp. 127-147. 
(2004) 'The politics of the new music', in P. Murray and P. Wilson (eds.), Music and the Muses: The Culture of Mousikê in the Classical Athenian City, Oxford: Oxford University Press, pp. 207-248.

(2007) 'The men who built the theatres: Theatropolai, Theatronai, and Arkhitektones', in P. Wilson (ed.), The Greek Theatre and Festivals: Documentary Studies, Oxford: Oxford University Press, pp. 87-121.

(2010) Actors and Icons of the Ancient Theater, Chichester: Wiley-Blackwell.

Csapo, E. and Miller, M. C. (2007) The Origins of Theater in Ancient Greece and Beyond, Cambridge: Cambridge University Press.

Csapo, E. and Slater, W. (1995) The Context of Ancient Drama, Ann Arbor, MI: University of Michigan Press.

da Rios, R. (1954) Aristoxeni Elementa Harmonica, Rome: Typis Publicae Officinae Polygraphicae.

di Benedetto, V. (1971) Euripide: Teatro e Società, Turin: Einaudi.

Easterling, P. (1994) 'Euripides outside Athens: A speculative note', Illinois Classical Studies, 19: $73-80$.

Emlyn-Jones, C. (2004) 'The dramatic poet and his audience: Agathon and Socrates in Plato's Symposium', Hermes, 132(4): 389-405.

Fischer-Lichte, E. (1982) 'The theatrical code: An approach to the problem', in E. W. B. HessLüttich (ed.), Multimedia Communication 2: Theatre Semiotics, Tübingen: Gunther Narr, pp. $46-62$.

Goldhill, S. (1990) 'The great Dionysia and civic ideology', in J. J. Winkler and F. I. Zeitlin (eds.), Nothing to do with Dionysus: Athenian Drama in its Social Context, Princeton: Princeton University Press, pp. 97-129.

- (1994) 'Representing democracy: Women at the great Dionysia', in R. Osborne and S. Hornblower (eds.), Ritual, Finance, Politics: Athenian Democratic Accounts Presented to David Lewis, Oxford: Oxford University Press, pp. 347-370.

- (1997) 'The audience of Greek tragedy', in P. Easterling (ed.), The Cambridge Companion to Greek Tragedy, Cambridge: Cambridge University Press, pp. 54-68.

$-(2000)$ 'Civic ideology and the problem of difference: The politics of Aeschylean tragedy, once again', Journal of Hellenic Studies, 120: 34-56.

Green, J. R. (1994) Theatre in Ancient Greek Society, London and New York: Routledge.

Habermas, J. (1989) The Structural Transformation of the Public Sphere: An Inquiry into a Category of Bourgeois Society, trans. T. Burger, Cambridge, MA: The MIT Press.

Hall, E. (1989) Inventing the Barbarian: Greek Self-Definition through Tragedy, Oxford: Oxford University Press.

Harris, E. M. (2002) 'Workshop, marketplace, and household: The nature of technical specialization in Classical Athens and its influence on economy and society', in P. Cartledge, E. E. Cohen, and L. Foxhall (eds.), Money, Labour, Land: Approaches to the Economies of Ancient Greece, London and New York: Routledge, pp. 67-99.

Henderson, J. (1991) 'Women and the Athenian dramatic festivals', Transactions of the American Philological Association, 121: 133-148.

-(1993) 'Comic hero versus political elite', in A. Sommerstein, S. Halliwell, J. Henderson, and B. Zimmermann (eds.), Tragedy, Comedy, and the Polis: Papers from the Greek Drama Conference, Nottingham 18-20 July 1990, Bari: Levante Editore, pp. 307-319.

Kaimio, M. (1999) 'The citizenship of the theatre-makers in Athens', Würzburger Jahrbücher für die Altertumswissenschaft, 23: 43-61.

Katz, M. A. (1998) 'Did women of Ancient Athens attend the theater in the eighteenth century?', Classical Philology, 93(2): 105-124.

Kennedy, D. (2009) The Spectator and the Spectacle: Audiences in Modernity and Postmodernity, Cambridge: Cambridge University Press.

Livingstone, S. (2005) 'On the relations between audiences and publics', in S. Livingstone (ed.), Audiences and Publics: When Cultural Engagement Matters for the Public Sphere. Changing Media, Changing Europe, vol. 2, Bristol: UK Intellect, pp. 17-41. 
Lloyd, D. and Thomas, P. (1998) Culture and the State, New York and London: Routledge. Marshall, C. W. and van Willigenburg, S. (2004) 'Judging Athenian dramatic competitions', Journal of Hellenic Studies, 124: 90-107.

Marx, K. (1975 [1843]) 'Contribution to the critique of Hegel's Philosophy of Law', in K. Marx and F. Engels, Collected Works, vol. 3, New York: International Publishers, pp. 5-129.

Osborne, M. J. (1981-1983) Naturalization in Athens, vols. 1-4, Brussels: Paleis der Academiën.

Pickard-Cambridge, A. (1988) The Dramatic Festivals of Athens, revised by J. Gould and D. M. Lewis, Oxford: Oxford University Press.

Rancière, J. (2004) Disagreement: Politics and Philosophy, trans. J. Rose, Minneapolis, MN: University of Minnesota Press.

Ravel, J. S. (1999) The Contested Parterre: Public Theater and French Political Culture, 1680-1791, Ithaca, NY and London: Cornell University Press.

Rehm, R. (2002) The Play of Space: Spatial Transformations in Greek Tragedy, Princeton, NJ: Princeton University Press.

-(2007) 'Festivals and audiences in Greece and Rome', in M. MacDonald (ed.), The Cambridge Companion to Greek and Roman Theatre, Cambridge: Cambridge University Press, pp. 184-201.

Revermann, M. (2006) 'The competence of theatre audiences in fifth- and fourth-century Athens', Journal of Hellenic Studies, 126: 99-124.

Rhodes, P. J. (2003) 'Nothing to do with democracy: Athenian drama and the polis', Journal of Hellenic Studies 123: 104-119.

Roselli, D. K. (2011) Theater of the People: Spectators and Society in Ancient Athens, Austin, TX: University of Texas.

- (forthcoming) 'Social class', in M. Revermann (ed.), The Cambridge Companion to Greek Comedy, Cambridge: Cambridge University Press.

Schiller, F. (1895 [1794]) Aesthetical and Philosophical Essays, New York: Harvard Publishing Co.

Schnurr-Redford, C. (1995) Frauen im klassischen Athen: Sozialer Raum und reale Bewegungsfreiheit, Munich: Oldenbourg.

Scullion, S. (1994) Three Studies in Athenian Dramaturgy, Stuttgart: B. G. Teubner.

Shepherd, S. and Wallis, M. (2004) Drama/Theatre/Performance, New York and London: Routledge.

Spineto, N. (2005) Dionysos a Teatro: Il Contesto Festivo del Dramma Greco, Rome: L'Erma di Bretschneider.

Taplin, O. (1999) 'Spreading the word through performance', in S. Goldhill and R. Osborne (eds.), Performance Culture and Athenian Democracy, Cambridge: Cambridge University Press, pp. 33-57.

-(2007) Pots and Plays: Interactions between Tragedy and Greek Vase-Painting of the Fourth Century, Los Angeles, CA: J. Paul Getty Museum.

Tzanetou, A. (2012) City of Suppliants: Tragedy and the Athenian Empire, Austin, TX: University of Texas.

Ubersfeld, A. (1981) L'école du spectateur: Lire le théatre, vol. 2, Paris: Éditions sociale.

Vernant, J.-P. (1988 [1972]) 'The historical moment of tragedy in Greece: Some of the social and psychological conditions', in J.-P. Vernant and P. Vidal-Naquet (eds.), Myth and Tragedy in Ancient Greece, trans. J. Lloyd, New York: Zone Books, pp. 23-28.

Vlassopoulos, K. (2007) 'Free spaces: Identity, experience, and democracy in Classical Athens', Classical Quarterly, 57(1): 33-52.

Walcot, P. (1971) 'Aristophanic and other audiences', Greece and Rome, 18(1): 35-50.

Wiles, D. (1997) Tragedy in Athens: Performance Space and Theatrical Meaning, Cambridge: Cambridge University Press.

(2011) Theatre and Citizenship: The History of a Practice, Cambridge: Cambridge University Press.

Wilson, P. (2008) 'Costing the Dionysia', in M. Revermann and P. Wilson (eds.), Performance, Iconography, Reception: Studies in Honour of Oliver Taplin, Oxford: Oxford University Press, pp. 88-127. 
(2009) 'Tragic honours and democracy: Neglected evidence for the politics of the Athenian Dionysia', Classical Quarterly, 59(1): 8-29.

Wohl, V. (2002) Love among the Ruins: The Erotics of Democracy in Classical Athens, Princeton, NJ: Princeton University Press.

Zeitlin, F. (1996) Playing the Other: Gender and Society in Classical Greek Literature, Chicago, IL: University of Chicago Press.

\section{Taylor \& Francis Not for distribution}

